\title{
EQUiLIBRIUM
}

Quarterly Journal of Economics and Economic Policy

2014 VOLUME 9 ISSUE 4, December

p-ISSN 1689-765X, e-ISSN 2353-3293

www.economic-policy.pl

Olczyk, M. (2014). Structural Heterogeneity Between EU 15 and 12 New EU Members - the Obstacle to Lisbon Strategy Implementation?. Equilibrium. Quarterly Journal of Economics and Economic Policy, 9(3), pp. 21-43, DOI: http://dx.doi.org/10.12775/EQUIL.2014.023

Magdalena Olczyk*

Gdansk University of Technology, Poland

\section{Structural Heterogeneity Between EU 15 and 12 New EU Members - the Obstacle to Lisbon Strategy Implementation?}

JEL Classification: $C 00$; E60; O52; P11

Keywords: Lisbon targets; European Union; multivariate analysis; structural indicators

\begin{abstract}
The aim of this article is to identify diversity between the EU-15 and the New Members in their implementation of the Lisbon Strategy in the period 20002010. By analyzing a set of structural indicators, we aim to fill a gap in the literature: the lack of publications providing complex evaluation of the implementation of the Lisbon Strategy using measurable indicators. Given their suitability for international comparisons, we use two taxonomic methods: Ward's cluster analysis and the synthetic variable method proposed by Hellwig.

The results of our analyses confirm the hypothesis of a large gap between the EU-15 countries and the 12 New Members in the key areas of the Lisbon Strategy. According to rankings given by our taxonomic analyses, a high level of the indicators selected is confirmed only for the EU-15 countries and only three New Members belong to a group presenting the average level of these indicators. This study demonstrates a need for a significant intensification of the EU cohesion policy, which is one of the main tools for achieving the Lisbon Strategy goals.
\end{abstract}

(C) Copyright Institute of Economic Research \& Polish Economic Society Branch in Toruń Date of submission: April 12, 2014; date of acceptance: June 9, 2014

* Contact: magdalena.olczyk@zie.pg.gda.pl, Gdansk University of Technology, Faculty of Economics, Traugutta Street 79, 80-233 Gdansk, Poland 


\section{Introduction}

The original Lisbon Strategy was launched in the year 2000 and assumed that the EU would "become the most dynamic and competitive knowledgebased economy in the world by 2010, capable of sustainable economic growth with more and better jobs and greater social cohesion and respect for the environment" (European Parliament, 2000). Unfortunately, the strategy's goals have not been fully achieved (Codogno et al., 2009; Teichman \& Brocka-Palacz, 2009). Some of the main reasons for this were: multiple objectives and programmes in the strategy with an unclear division of responsibilities; unfavourable economic situation outside Europe; no link between the Lisbon Strategy and other EU instruments (Lenain et al., 2005), the various sectoral initiatives and policy measures (Barbier, 2010; Barrel \& Kirby 2007), and a lack of institutional leadership to monitor the progress and to stimulate engagement in fulfilment of the Lisbon Strategy's goals (Papadimitriou \& Copeland, 2012).

Therefore, in order to better prepare the EU for the next decade, the European Commission has announced a new "Europe 2020 Strategy", with three key drivers: smart growth (fostering knowledge, innovation, education and a digital society); sustainable growth (making production more resource-efficient while boosting competitiveness); and inclusive growth (increasing participation in the labour market, the acquisition of skills and the fight against poverty). The strategy sets five targets, which define where the EU should be by 2020 , and against which progress can be tracked: $75 \%$ of the population aged 20-64 should be employed; 3\% of the EU's GDP should be invested in R\&D; the "20/20/20" climate/energy targets should be met; the share of early school leavers should be under 10\%; at least $40 \%$ of the younger generation should have a tertiary education qualification; and 20 million fewer people should be at risk of poverty (European Commission, 2010a). The large diversity of the above mentioned objectives involves a wide set of structural indicators to monitor the implementation of the Lisbon Strategy (see methodology).

The achievement of these objectives requires even greater cooperation between the Member States and the ongoing monitoring of each country's implementation of this strategy. This applies in particular to the $12 \mathrm{New}$ Members of the EU. In the publications relating to the new EU strategy, we meet the statement that the main barrier to achieving its objectives may be a large gap in the key areas between the EU-15 countries and the 12 new EU Members (Cantillon, 2010). The aim of this article is to verify this hypothesis of a large and sustained diversity between the EU-15 and the 12 New Members in their implementation of the Lisbon Strategy's objectives between the years 2000 and 2010. That period of analysis has been chosen 
because the Lisbon Strategy was adopted in 2000, and it should have resulted in making the EU "the most competitive and dynamic knowledgedriven economy" by 2010 .

The article's research questions are as follows. Over the years 20002010, how did the New EU Members differ in relation to the EU15 countries in the key indicators of implementation of the Lisbon Strategy? Which country (among the New Members) could be called the leader in the implementation of the strategy? What are the strengths and weaknesses of one transition economy (taking the case of Poland) compared to the other new member states according to the indicators selected? The answers will help determine the distance between the New EU countries and the EU-15 in their achievement of the Strategy's goals and provide an assessment of the starting position of the New Members for implementation of the Europe 2020 Strategy.

\section{Literature review}

So far, analyses relating to assessment of the Lisbon Strategy's achievements do not give a complete picture of the process (Amstrong et al., 2008; Borsi, 2009). The available reports mainly focus on two aspects (European Commission, 2004; 2005; 2007). Firstly, they identify and analyze the bottlenecks at the EU level, which are common to most countries, that mainly contributed to the Lisbon Strategy's failure (European Commission, 2010a; $2010 \mathrm{~b} ; 2010 \mathrm{c})$. In some cases, we find reports evaluating the realization of a selected aspect of the Lisbon strategy, e.g. a report concerning employment and social policy (European Parliament, 2010; Barbier, 2012; Krings et al., 2012) or one related to the knowledge economy (Johansson et al., 2007).

Secondly, among the empirical analyses, reports on national Lisbon Strategy implementation dominate, e.g. a report on Austria (Ederer at al., 2010), on the Czech Republic and Finland (Sojka 2007), and on each EU Member State (Koczor \& Tokarski, 2011). These evaluations focus mainly on identifying the necessary steps in the adjustment of national economic policy to support a growth in coherence of the EU internal market and thus the achievement of the objectives of the Lisbon Strategy. Very often these analyses are not based on measureable indicators, but on benchmarking method (Brauers et al., 2011; Bauers et al., 2012), the peer comparison or best practices (Arpaia, 2007). An example of the few studies assessing the degree of implementation of the Lisbon strategy based on quantifiable measures are publications using multivariate analysis methods e.g. the assessment analysis of the implementation of the Lisbon Strategy by the 27 
EU countries (Balcerzak et al., 2008) or the analysis assessing the position of Poland in relation to the other EU countries at the start of the Europe 2020 plan (Balcerzak, 2011).

What type of evaluation of the implementation of the Lisbon Strategy can be found in the existing analyses? First of all, they focus on macroeconomic factors, which fail to provide a clear assessment of the implementation of the strategy and they recommend a cautious interpretation of the macroeconomic data. The period analyzed is the time when Europe and the world were affected by the economic crisis and the EU expanded with 12 New Members. In fact, the goals of the Lisbon strategy assumed annual growth in the EU economy at 3\% (34.4\% in the decade), while in the period from 2000 to 2010 real GDP grew by $16.4 \%$ in all EU countries but by only $15 \%$ in the EU15. The worst situation was to be found in Italy (real GDP in year 2009 was equal to GDP in year 2001), and the best in Poland. The paradox of the Polish economy is that actually the best macroeconomic situation was accompanied by the low degree of implementation of the Lisbon Strategy targets. Also, starting in the year 2008 sovereign debt crisis spilled out into all EU countries. Currently, the excessive deficit procedure has been opened in all Member States, with the exception of Estonia, Luxembourg and Sweden. In 2009-2010, the public finances condition measured by public deficit in relation to GDP looked bad in Ireland (30,6\% in $2000)$, Greece (10.7\%), Portugal (9.8\%) and Spain (9,1\%). So, the impact of negative, exogenous factors on the Member States' performance in the period analyzed was significant.

In the context of the above, the assessment of the strategy is difficult, but numbers alone speak for themselves and it is difficult to get a positive answer to the question "Was the Lisbon Strategy successful?" (Treidler, 2011). The fundamental objectives, such as a $70 \%$ employment rate in the EU internal market (only 64.6\% in year 2010) and an expenditure on R\&D at the level of $3 \%$ of GDP (2\% in the year 2010), have not been met (Eurostat 2012). Moreover, the EU has not become an area of high-speed Internet access, as only $30 \%$ of the EU's rural population have access to the Internet (Eurostat 2012). Furthermore, various negative phenomena in the key areas of the Lisbon Strategy do not allow us to positively evaluate the process, e.g. high long-term unemployment in several EU countries (Slovakia, Ireland, Latvia, Spain and Greece), high levels of poverty risk in many MS countries, such as Bulgaria, Romania, Latvia and Lithuania (Bertolini \& Pagliacci, 2010), a high level of early school leavers, especially in Spain, Malta, Portugal and Italy (European Commission, 2011), and low levels of lifelong learning in several countries, such as Bulgaria, Greece, Romania, Hungary, Slovakia and Poland (Panitsidou et al., 2012). 
Of course some of the objectives of the Lisbon Strategy have been met. The female employment rate increased by four percentage points, i.e. from $54 \%$ to $58 \%$ in the years $2000-2010$. Additionally, the Strategy has had some impact on the employment rate of older workers aged between 55 and 64, which increased from $37 \%$ in 2000 to $47 \%$ in 2010 in the EU (Destefanis \& Mastromatteo, 2012). Implementation of the Lisbon Strategy has contributed to public acceptance of social reforms in some countries, e.g. France's pension reform in 2002 and Germany's unemployment reform in 2004 (Zgajewski \& Hajjar, 2005).

Reports assessing the Lisbon Strategy provide much detail about the causes of failures in its implementation. The most often cited reasons are: a multiplicity of targets and a lack of commitment at national level to priorities (Mundschenk, 2006); deficiencies in economic governance with open coordination methods (Mundschenk, 2006); no link between the Strategy and other EU instruments (Blanke \& Kinnock, 2010); lack of good publicity about the Strategy's goals (Radło, 2006); and the uneven impact of the European Commission's recommendations for different EU countries (European Commission, 2010d). Sometimes, the emphasis is put on structural causes of failure to implement. Generally, in the opinion of many economists, the structures of the European economies were not prepared for such quick changes as were proposed in the Lisbon Strategy (Moniz, 2011). According to Tausch, for example, the disappearance of enterprising capitalist families and the current incompatibility of work and family life explain much of the failure of the Lisbon process (Tausch, 2009).

Therefore, effective implementation of the objectives of the New 2020 Strategy will require overcoming a few new challenges. The success of the New Strategy will mostly depend on an ability to learn from the limitations of the Lisbon Strategy (Vilpišauskas, 2012). First of all, priorities such a climate change, sustainable energy, the retirement age, and investments in education and skills must be closely connected with key reforms in the EU area (Kedaitiene \& Kedaitis, 2009; Fischer et al., 2010). A political commitment to reform is necessary, i.e. the choice between a social model and the competitiveness of the EU economy must be made (Gros, 2012). The chosen priorities should strengthen Europe's approach to globalization and make the European economy more resilient to global challenges (Rodrigues, 2009). All this requires further reinforcement of existing governance mechanisms, with the Commission in the driver's seat (Soriano \& Mulatero, 2010).

Sometimes, a sine qua non condition for achieving the objectives of the New Strategy is indicated to free the potential of the EU internal market. EU countries, whose priority is to increase competitiveness, cannot pursue the integration process on the basis of the lowest common denominator. 
They must form themselves into small groups to later give impetus to the growth of the entire EU internal market This is why not only the present complex analysis of the implementation of the Lisbon Strategy, but also an assessment of the similarities between countries in the implementation of the EU strategy is so important. The literature offers no such publications relating to a complex evaluation of the implementation of the Lisbon Strategy using measurable indicators that would allow an assessment of the effects of the implementation strategy of each EU country in comparison to the others. It is hoped that the present article will fill this gap.

\section{Methodology and selection of diagnostic variables}

For the analysis, a set of structural indicators are used which were established by the European Commission to monitor the implementation of the Lisbon Strategy. A shortlist has been chosen consisting of 14 key indicators, although the full detailed list contains a set of seventy-nine indicators. The structural indicators selected have been chosen to track the progress of the four main objectives: investing in knowledge and innovation; unlocking business potential; investing in people and modernizing labour markets; and climate and energy changes.

The analysis employs data for the 12 New EU members and for the EU15 average in 2000 and 2010. The data refer to 14 structural indicators, defined as diagnostic variables $\mathrm{x}_{1}$ to $x_{14}$ (Table 1 ).

First, the usefulness of the diagnostic variables was determined by examining their degree of variation and correlation. The analysis requires those variables which have sufficient spatial variability and are not correlated too strongly with each other. Only in this case will they be good carriers of information, allowing different processes to be identified (Grabiński et al., 1993).

The threshold value chosen for the coefficient of variation is 0.1 , and for the correlation coefficient, 0.7. (Nowak, 1990). Due to the very low value of the coefficient of variation for variable $x_{3}$ (Education level of young people aged 20-24), it was excluded from the analysis. From among very different distance (similarity) matrices, Euclidean distance is chosen as it is the recommended distance measure for Ward's method (Kaufman \& Rousseeuw, 1990; Everitt et al., 2001). The Euclidean distance is the geometric distance in multidimensional space and it is computed as the square root of the sum of the squared differences in the value of the variables. 
Table 1. A set of diagnostic variables (structural indicators)

\begin{tabular}{|c|c|c|}
\hline & $\begin{array}{l}\text { Structural } \\
\text { indicators }\end{array}$ & Definition \\
\hline$x_{1}$ & $\begin{array}{l}\text { Per capita Gross } \\
\text { Domestic Product }\end{array}$ & $\begin{array}{l}\text { Per capita GDP in Purchasing Power Standard (PPS). } \\
\text { EU15 = } 100 \text { Per capita GDP in Purchasing Power Standard } \\
\text { (PPS).EU15 = } 100\end{array}$ \\
\hline$x_{2}$ & $\begin{array}{l}\text { Labour productivi- } \\
\text { ty. }\end{array}$ & $\begin{array}{l}\text { Work productivity per person employed GDP in PPS per } \\
\text { person employed.EU15 }=100\end{array}$ \\
\hline$x_{3}$ & $\begin{array}{l}\text { Education level of } \\
\text { young people (aged } \\
20-24) \text {. }\end{array}$ & $\begin{array}{l}\text { Percentage of young people aged } 20-24 \text { having reached at } \\
\text { least higher secondary education or training, expressed as a } \\
\text { percentage of the total population of the same age group. }\end{array}$ \\
\hline$x_{4}$ & $\begin{array}{l}\text { Research and } \\
\text { technological } \\
\text { development } \\
\text { (R\&TD). }\end{array}$ & $\begin{array}{l}\text { Gross domestic expenditure on research and development } \\
\text { (GERD) as a percentage of GDP. }\end{array}$ \\
\hline$x_{5}$ & $\begin{array}{l}\text { Comparative price } \\
\text { levels. }\end{array}$ & r parities (PPP) and market \\
\hline$x_{6}$ & $\begin{array}{l}\text { Business invest- } \\
\text { ment. }\end{array}$ & $\begin{array}{l}\text { ormation (GFCF) in the private sector } \\
\text { DP. }\end{array}$ \\
\hline$x_{7}$ & Employment rate. & $\begin{array}{l}\text { ged } 15-64 \text { as a percentage of the total } \\
\text { he age group. }\end{array}$ \\
\hline$x_{8}$ & $\begin{array}{l}\text { Employment rate } \\
\text { of older workers. }\end{array}$ & $\begin{array}{l}\text { as a percentage of the total } \\
\text { up. }\end{array}$ \\
\hline$x_{9}$ & $\begin{array}{l}\text { At-risk-of-poverty } \\
\text { rate after social } \\
\text { transfers. }\end{array}$ & $\begin{array}{l}\text { Percentage of persons with an equivalised disposable in- } \\
\text { come below the risk-of-poverty threshold after social trans- } \\
\text { fers. The threshold is set at } 60 \% \text { of the national median } \\
\text { equivalised disposable income (after social transfers). }\end{array}$ \\
\hline$x_{10}$ & $\begin{array}{l}\text { Dispersion of } \\
\text { regional employ- } \\
\text { ment rates. }\end{array}$ & $\begin{array}{l}\text { Coefficient of variation of employment rates across regions } \\
\text { (NUTS } 2 \text { level) within countries. }\end{array}$ \\
\hline$x_{11}$ & $\begin{array}{l}\text { Long term unem- } \\
\text { ployment. }\end{array}$ & $\begin{array}{l}\text { Total long-term unemployed (over } 12 \text { months) as a per- } \\
\text { centage of the total active population aged } 15-64 \text {. }\end{array}$ \\
\hline$x_{12}$ & $\begin{array}{l}\text { Greenhouse gases } \\
\text { emissions. }\end{array}$ & $\begin{array}{l}\text { Percentage change in aggregated emissions of } 6 \text { main } \\
\text { greenhouse gases }(\mathrm{CO} 2, \mathrm{CH} 4, \mathrm{~N} 2 \mathrm{O}, \mathrm{HFCs}, \mathrm{PFCs} \text { and SF6) } \\
\text { expressed in } \mathrm{CO} 2 \text {-equivalents. The base year for the Kyoto } \\
\text { Protocol objectives and the Decision of the EU Council } \\
\text { Decision is 2008-2012. Index base year }=100\end{array}$ \\
\hline$x_{13}$ & $\begin{array}{l}\text { Energy intensity of } \\
\text { the economy. }\end{array}$ & $\begin{array}{l}\text { Gross domestic consumption of energy divided by GDP (at } \\
\text { constant prices, } 1995=100 \text { ). }\end{array}$ \\
\hline$x_{14}$ & $\begin{array}{l}\text { Freight } \text { transport } \\
\text { volume. }\end{array}$ & $\begin{array}{l}\text { Index of freight transport volume relative to GDP. Meas- } \\
\text { ured in tonne-km/GDP and indexed on } 1995 \text {. }\end{array}$ \\
\hline
\end{tabular}

Source: http://epp.eurostat.ec.europa.eu/portal/page/portal/structural_indicators/intr oduction/.

Due to different scales or magnitude across the data, we should normalize them. This is necessary due to differing scales or magnitudes among the variables. In general, variables with greater dispersion (i.e. with higher standard deviations) have more impact on the final similarity measure, so 
the purpose of standardization is for each variable to be equally represented in the distance measure.

The Z-score standardization method is used, which compares each value of variable $x_{i}$ to the mean and then divides it by the standard deviation:

$$
z_{i j}=\frac{x_{i j}-\bar{x} j}{s d_{j}}
$$

where:

$z_{\mathrm{ij}}-$ the standardized value of the $j$-th variable on object $i$;

$\mathrm{x}_{\mathrm{ij}}$ - the value of the $j$-th variable on object $i$;

$\bar{x}_{j}$ - the mean value of the $j$-th variable;

$s d_{j}$ - the standard deviation of the $j$-th variable.

After standardization, the average of each standardized variable is equal to zero and the standard deviation for each variable is equal to 1 .

In this article, two taxonomic methods are used to identify the diversity between the UE 15 and the 12 New Members in their implementation of the Lisbon Strategy. First, to group the countries analyzed in relatively homogeneous groups we apply cluster analysis (Gordon, 1999; Everitt, 1993). This method allows a determination of the similarity of objects, without establishing a hierarchy among them. We use Ward's method, which is based on an analysis of variance to evaluate the distances between clusters, i.e. it attempts to minimize the sum of the squared distances of points from the cluster's centroid. The cluster procedure in Ward's method is as follows. The pair of sample units that yield the smallest error sum of squares, that is, the largest $r^{2}$ value, forms the first cluster. In the second step of the algorithm, $n-2$ clusters are formed from the $n-1$ clusters defined in step 1. These may include two clusters of size 2 , or a single cluster of size 3 including the two items clustered in step 1. Again, the value of $r^{2}$ is maximized. Thus, at each step of the algorithm clusters or observations are combined in such a way as to minimize the results of error from the squares, in other words maximizing the $r^{2}$ value. The algorithm stops when all the sample units are combined into a single large cluster of size $n$. (Ward, 1963). The error sum of squares and $r^{2}$ values are then computed, using the following formula:

$$
\text { ESS (error sum of squares) }=\sum_{i} \sum_{j} \sum_{k}\left|x_{i j k}-\bar{x}_{i k}\right|^{2} \text {, }
$$

TSS (total sum of squares) 


$$
\left(\mathrm{r}^{2}\right)=\boldsymbol{T S} \boldsymbol{S}-\boldsymbol{E S S} / \boldsymbol{T S S},
$$

where:

$x_{i j k}$ - the value for variable $k$ in observation $j$ belonging to cluster $i$,

$\bar{x}_{i k}-$ cluster means for variable $\mathrm{k}$,

$\bar{x}_{k}-$ mean for variable $\mathrm{k}$.

The second method used is a ranking of the objects (countries), which is based on the value of a synthetic variable (Johnson \& Wichern, 2007). There are a variety of methods for creating a synthetic variable (Hellwig, 1968; Strahl, 1978; Grabiński, 1992; Grabiński et al., 1993; Zeliaś, 2002). We use two different methods to calculate the synthetic variable. First, we obtain a synthetic value $(y)$ as the arithmetic mean of the normalized features of each variable. The synthetic value $\left(y_{i}\right)$ is calculated using the following formula:

$$
\mathrm{y}_{\mathrm{i}}=\sum_{\mathrm{j}=1}^{\mathrm{m}}\left(\mathrm{x}_{\mathrm{ij}} * \mathrm{~b}_{\mathrm{j}}\right),
$$

where:

$\mathrm{m}-$ the number of features,

$b_{j}=1 / m, \sum_{j=1}^{m} b_{j}=1$, and $x_{i j}-$ the normalized values of the matrix $X$, where all the features are stimulants.

The synthetic variable is in the range [0,1]. A higher value indicates the object having a more favourable position. Before starting to calculate the synthetic variable, de-stimulants must be replaced by stimulants in the variable matrix and then the matrix must be normalized.

For the first operation we use the following formula:

$$
\mathrm{x}_{\mathrm{i}}^{\prime}=2 \overline{\mathrm{x}}-\mathrm{x}_{\mathrm{i}}
$$

where: $x_{i}$ is the de-stimulant value, $\bar{x}$ is the mean value of the de-stimulant

Then, for the normalization we use the formula:

$$
x_{i}^{\prime \prime}=\left(x_{i}-x_{\min } / x_{\max }\right)^{p}
$$

where:

$\mathrm{x}_{\mathrm{i}}$ - the stimulant value, $\mathrm{p}=1$. 
Calculating the synthetic variable by a second method, we follow the methodology proposed by Hellwig. In this method we first choose an "ideal object", which is described by a set of the maximum values of each variable. Of course, the variable matrix must be normalized and contain only stimulants. Then we calculate the synthetic variable using the following formula:

$$
d_{i}=1-\frac{c_{i o}}{c_{0}}
$$

where:

$\mathrm{d}_{\mathrm{i}}$ - the taxonomic measure of development proposed by Hellwig,

$\mathrm{c}_{\mathrm{io}}$ - the Euclidean distance between the country and the "ideal object",

$\mathrm{c}_{\mathrm{o}}$ - the critical distance between objects and the "ideal object",

$c_{o}=\overline{c_{o}}+2 S d$,

$\overline{c_{O}}=\frac{1}{n} \sum_{i=1}^{n} c_{i o}$,

$S d=\left[\frac{1}{n} \sum_{i=1}^{n}\left(c_{i o}-\bar{c}\right)^{2}\right]^{1 / 2}$,

$c_{i o}=\left[\sum_{i=1}^{n}\left(x_{i j}-x_{\max }\right)^{2}\right]^{1 / 2}$,

$\mathrm{x}_{\mathrm{ij}}$ - the normalized values of the matrix X.

Based on the value of the synthetic variable (the average $\bar{d}_{l}$ and the standard deviation $S d_{i}$ ), all the countries analyzed can be divided into four groups. The first group includes the best countries, for which the distance from the "ideal object" exceeds values $\bar{d}_{l}+S d_{i}$. The second group consists of countries, for which the distance from the "ideal object" is in the range $\bar{d}<d_{i}<\bar{d}+S d_{i}$. In the third group there are countries for which the

distance from the "ideal object" is in the range $\bar{d}-S d<d_{i}<\bar{d}$. The last group (the worst one) is comprised of countries having a distance from the "ideal object" not exceeding the value $\bar{d}_{l}-S d_{i}$. All the statistical analyses in this article were performed using the statistical software Statistica 11.0, SPSS version 21.0 and R software.

\section{Empirical analysis}

After verification of the determinants which describe the degree of implementation of the Lisbon Strategy by the New Members of the EU-27, similarity matrices of the objects, called distance matrices, are built for the years 2000 and 2010. Based on these matrices, two dendrograms are created. They show how many clusters, i.e. homogeneous groups of countries, can be found among the 12 New Members of the EU-27. The interpretation 
of the dendrogram, i.e. the identification of the number of clusters, depends on which bond distance we choose as the point of interpretation. In this analysis we choose a sixth bond distance as the interpretation line. Using Ward's method, in 2000 four large homogenous groups of countries (clusters) can be distinguished (Figure 1).

Figure 1. Classification of 12 New EU Members and the EU-15 group, based on Ward's method and square Euclidean distance in year 2000

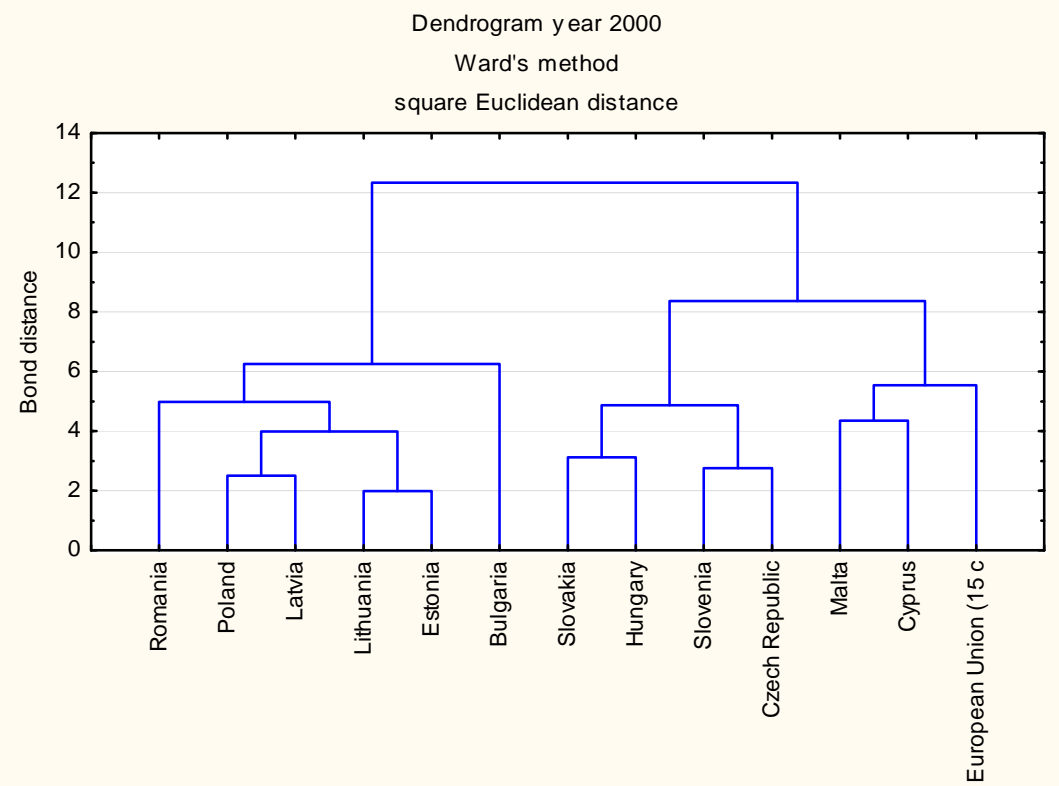

Source: own calculations based on Eurostat (2012).

Group A includes the EU-15, Cyprus and Malta. This group can be divided into two smaller clusters, i.e. the EU-15 countries in the first, and Cyprus and Malta in the second. Group B consists of four countries: The Czech Republic, Hungary, Slovakia and Slovenia. In this group, The Czech Republic and Slovenia are very similar to each other and form a small separate cluster, as do Hungary and Slovakia. Group C contains five countries: Romania, Poland, Estonia, Lithuania and Latvia. Here too, we can distinguish small homogeneous clusters: Estonia with Lithuania, Latvia with Poland, and a one-object cluster, Romania. The last group D consists of only one country, Bulgaria, which is a very different object from the rest of 
group C. Furthermore, the dendrogram analysis shows that countries in groups A and B differ strongly from those in groups C and D.

Analyzing the dendrogram for 2010 reveals significant changes. Only the number of large homogeneous clusters does not change during the period analyzed (Figure 2).

Figure 2. Classification of 12 New EU Members and the EU-15 group, based on Ward's method and square Euclidean distance in year 2010

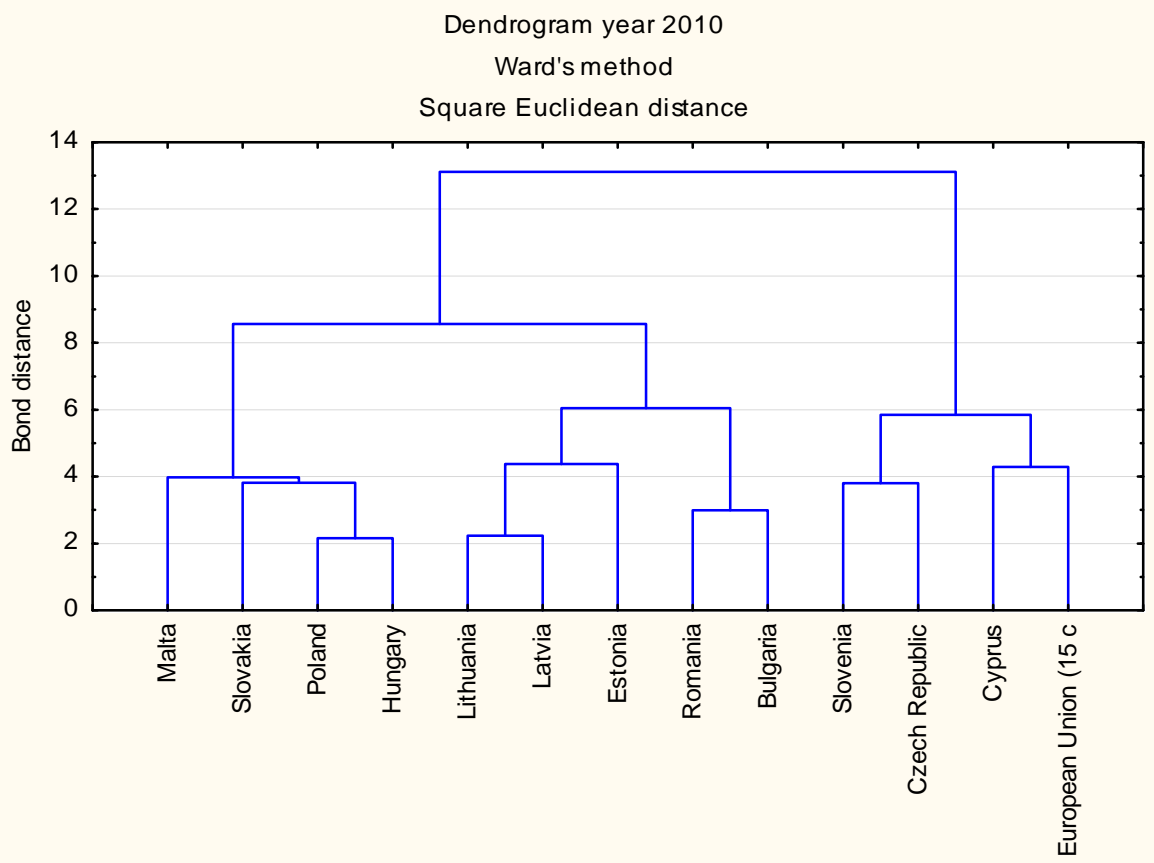

Source: own calculations based on Eurostat (2012).

In group A, there are only two objects, Cyprus and the EU-15 countries, and also in group B, Slovenia and the Czech Republic. Clusters A and $\mathrm{B}$ have become significantly more similar to each other, reducing the distance between them from nine to six bond distances between over the period 2000-2010. Therefore, the EU-15 countries, Cyprus, the Czech Republic and Slovenia can be treated as one big cluster of similar countries in terms of the intensity of their implementation of the Lisbon Strategy.

In groups $\mathrm{C}$ and $\mathrm{D}$, very big changes have taken place. Bulgaria has joined group C, but Poland has left it. In 2010, group C can be divided into 
two smaller clusters: Estonia, Lithuania and Latvia, with Lithuania and Latvia being much more similar to each other than to Estonia, and a second cluster consisting of Romania and Bulgaria. Group D consists of three countries that still in 2000 were relatively similar to the EU-15, Malta, Hungary and Slovakia, plus Poland, which has joined them. In this group, over the ten years, Poland has become much more similar to Hungary. The difference (distance) between the two larger groups of countries, A plus $\mathrm{B}$ and $\mathrm{C}$ plus $\mathrm{D}$, has changed very little over the years studied.

The above analysis allows grouping countries on the basis of the taxonomic similarity of multivariate objects (a distance matrix). If we assume that the New Member States aimed to achieve a similar level of structural indicators to those of the EU-15 countries, it is worth considering the distance that separates each New EU Member from the EU-15. For this purpose, we normalize the distance matrix, taking as a reference country the EU-15 group (see Table 2).

Table 2. Normalized distance matrices for 12 New UE Members in years 2000 and 2010 (reference country $=$ the EU15)

\begin{tabular}{|lc|l|c|}
\cline { 2 - 4 } \multicolumn{1}{c|}{} & Year 2000 & & Year 2010 \\
\hline UE 15 & $\mathbf{0 , 0 0 0}$ & UE15 & $\mathbf{0 , 0 0 0}$ \\
\hline Cyprus & 0,386 & Czech Republic & 0,486 \\
\hline Slovenia & 0,391 & Cyprus & 0,488 \\
\hline Malta & 0,417 & Slovenia & 0,541 \\
\hline Czech Republic & 0,562 & Malta & 0,554 \\
\hline Poland & 0,620 & Slovakia & 0,600 \\
\hline Hungary & 0,628 & Poland & 0,623 \\
\hline Latvia & 0,663 & Hungary & 0,635 \\
\hline Estonia & 0,721 & Latvia & 0,656 \\
\hline Slovakia & 0,742 & Estonia & 0,682 \\
\hline Lithuania & 0,746 & Lithuania & 0,702 \\
\hline Romania & 0,823 & Romania & 0,759 \\
\hline Bulgaria & 1,000 & Bulgaria & 1,000 \\
\hline
\end{tabular}

Source: own calculations based on Eurostat (2012).

Four countries definitely have the smallest distance from the EU-15, in both 2000 and 2010: Cyprus, Slovenia, Malta and the Czech Republic. The second group (a pursuit group) is unchanged and consists of the following countries: Slovakia, Poland, Hungary, Latvia and Estonia. The furthest 
from the EU-15 in achieving the Lisbon Strategy objectives in both years are three countries: Lithuania, Romania and Bulgaria.

To answer the question of which of the thirteen objects surveyed (12 New EU Member states and the countries of the EU-15) is the leader in the implementation of the Lisbon Strategy, it was decided to rank them according to the criterion of synthetic value. Table 3 shows the ranking of countries based on the value of the synthetic index, calculated as the arithmetic average of the normalized variables for each country.

Table 3. Countries ranking base on synthetic variable in years 2000 and 2010 (reference value $=\max$ value, method - the arithmetic mean)

\begin{tabular}{|l|c|l|c|l|c|}
\hline \multicolumn{1}{|c|}{ Country } & Year 2000 & Country & Year 2010 & \multicolumn{2}{c|}{ Ranking changes 2010/2000 } \\
\hline UE15 & 0,535 & UE15 & 0,494 & UE15 & no \\
\hline Cyprus & 0,467 & Cyprus & 0,416 & Cyprus & no \\
\hline Slovenia & 0,388 & $\begin{array}{l}\text { Rzech } \\
\text { Republic }\end{array}$ & 0,384 & $\begin{array}{l}\text { Czech Re- } \\
\text { public }\end{array}$ & 2 \\
\hline Malta & 0,361 & Slovenia & 0,372 & Slovenia & -1 \\
\hline $\begin{array}{l}\text { Czech } \\
\text { Republic }\end{array}$ & 0,345 & Malta & 0,326 & Malta & -1 \\
\hline Latvia & 0,323 & Estonia & 0,322 & Estonia & 1 \\
\hline Estonia & 0,314 & Latvia & 0,316 & Latvia & -1 \\
\hline Hungary & 0,314 & Lithuania & 0,312 & Lithuania & 2 \\
\hline Romania & 0,301 & Poland & 0,310 & Poland & 2 \\
\hline Lithuania & 0,299 & Slovakia & 0,310 & Slovakia & 2 \\
\hline Poland & 0,284 & Hungary & 0,304 & Hungary & -3 \\
\hline Slovakia & 0,236 & Romania & 0,298 & Romania & -3 \\
\hline Bulgaria & 0,153 & Bulgaria & 0,209 & Bulgaria & no \\
\hline
\end{tabular}

Source: own calculations based on Eurostat (2012).

The leader in both years is the group of EU-15 countries, while the second place belongs to Cyprus. In the top 5 group in both years there are also Slovenia, Malta and the Czech Republic. The Czech Republic has moved up most in the ranking between 2000 and 2010, i.e. from the fifth to the third place. In addition, the countries that record the biggest positive jumps in the ranking are Poland, Slovakia and Lithuania. The country with the lowest degree of achievement of the Lisbon Strategy objectives, i.e. with the last place in the ranking, is Bulgaria. Moreover, two countries, 
Romania and Hungary, show the biggest drops in the ranking between 2000 and 2010.

To check if the choice of EU15 as a comparative base was correct, the author has recalculated the data and created a new ranking with EU6 as a new base. The EU6 group consists of six countries (Belgium, Netherlands, Luxemburg, Germany, France, Italy), all of which signed the original Treaty of Rome in 1957 (Table 4).

Table 4. Countries ranking base on synthetic variable (Hellwig methodology), in years 2000 and 2010

\begin{tabular}{|l|c|l|c|l|c|}
\hline \multicolumn{1}{|c|}{ Country } & Year 2000 & \multicolumn{1}{c|}{ Country } & Year 2010 & \multicolumn{1}{c|}{ Country } & $\begin{array}{c}\text { Ranking } \\
\text { changes } \\
\mathbf{2 0 1 0} / \mathbf{2 0 0 0}\end{array}$ \\
\hline EU6 & 0,147 & EU6 & 1,798 & EU6 & no \\
\hline Denmark & 0,132 & Ireland & 1,374 & Ireland & +1 \\
\hline Ireland & 0,129 & Denmark & 1,374 & Denmark & -1 \\
\hline Austria & 0,128 & Austria & 1,345 & Austria & no \\
\hline Sweden & 0,121 & Sweden & 1,216 & Sweden & no \\
\hline United Kingdom & 0,108 & Finland & 0,857 & Finland & +1 \\
\hline Finland & 0,099 & United Kingdom & 0,828 & United Kingdom & -1 \\
\hline Spain & 0,060 & Spain & 0,354 & Spain & no \\
\hline Cyprus & 0,042 & Cyprus & 0,267 & Cyprus & no \\
\hline Malta & 0,040 & Malta & $-0,049$ & Malta & no \\
\hline Greece & 0,036 & Greece & $-0,077$ & Greece & no \\
\hline Portugal & 0,031 & Slovenia & $-0,178$ & Slovenia & +1 \\
\hline Slovenia & 0,025 & Portugal & $-0,293$ & Portugal & -1 \\
\hline Czech Republic & 0,000 & Czech Republic & $-0,322$ & Czech Republic & no \\
\hline Hungary & $-0,027$ & Slovakia & $-0,552$ & Slovakia & +2 \\
\hline Poland & $-0,041$ & Hungary & $-0,853$ & Hungary & -1 \\
\hline Slovakia & $-0,044$ & Estonia & $-0,896$ & Estonia & +1 \\
\hline Estonia & $-0,052$ & Poland & $-0,925$ & Poland & -2 \\
\hline Lithuania & $-0,055$ & Lithuania & $-0,968$ & Lithuania & no \\
\hline Latvia & $-0,060$ & Latvia & $-1,227$ & Latvia & no \\
\hline Romania & $-0,088$ & Romania & $-1,486$ & Romania & no \\
\hline Bulgaria & $-0,103$ & Bulgaria & $-1,586$ & Bulgaria & no \\
\hline & & & & & \\
\hline
\end{tabular}

Source: own calculations based on Eurostat (2012). 
The results shown in tables 3 and 4 do not differ dramatically; generally the EU15 countries performed better than EU12 in fulfilling the goals of the Lisbon Strategy. One can ask why such a situation takes place, if Estonia, Slovenia, the Czech Republic did much better in the past decade than Italy, Spain, Portugal and Greece. It is due to huge disproportion between EU15 countries and the New EU Members in the level of three indicators: the domestic product per capita, the labour productivity and the energy intensity of economy. The handicap the old EU countries have cannot be counterbalanced by better results in the remaining structural indicators in New Members States.

Objects that are next to each other in the ranking may not be similar. The best strategy to improve a position in the ranking is to conform with the object which has a better ranking but is also the most similar. So what is the best strategy for Poland to faster achieve the objectives of the Europe 2020 Strategy? A strategic development path is presented in Figure 3.

Figure 3. Recommended Polish path on Lisbon Strategy implementation

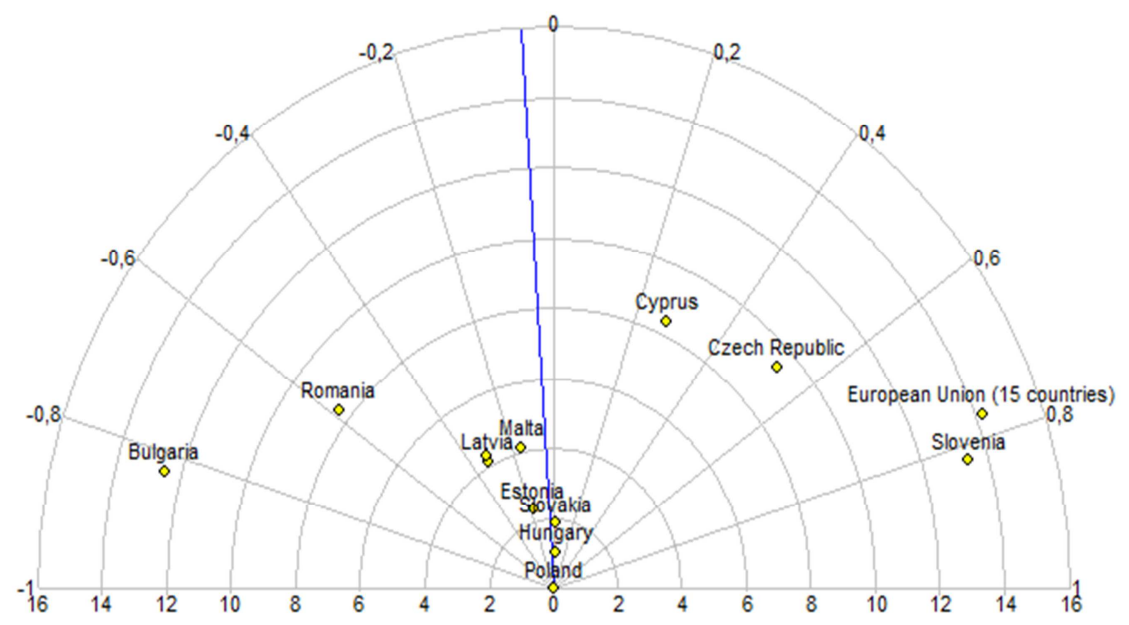

Source: own calculations base on calculations from table 4. Semicircles define the metric distance of all countries to a country located in the center at the bottom of the figure (Poland). Radiuses from right to left (anticlockwise) determine the positions of countries in the ranking. The numbers, placed at the end of the last radius of the semi-circle, represent the scale of the object values in the rankings.

Poland should mainly follow the path of the other Baltic States standing higher in the ranking, i.e. Lithuania, Latvia and Estonia and try to become more similar to the Maltese economy. It should therefore focus on increas- 
ing expenditures on research and development, and on improving the employment rate, particularly among older people (55-64 years). It would be inadvisable for it to embark on programmes to increase the degree of similarity of its economy to Cyprus or to the Czech Republic, because they are structurally quite different.

In order to verify the above ranking, the objects are also designated into four groups according to the Hellwig synthetic value calculated (table 5). This method allows the identification of countries with high, average, low and very low levels of achievement of the Lisbon Strategy's goals.

Table 5. Countries ranking base on synthetic variable (Hellwig methodology), in years 2000 and 2010

\begin{tabular}{|c|c|l|l|}
\hline \multicolumn{5}{|c|}{ Year 2000 } \\
\hline ranking & level & \multicolumn{1}{|c|}{ criterion } & \multicolumn{1}{c|}{ Country } \\
\hline I & high & di $>0,5150$ & UE 15 \\
\hline II & middle & $\begin{array}{l}0,3481<\mathrm{di}< \\
0,5140\end{array}$ & $\begin{array}{l}\text { Slovenia, Cyprus, Malta, Czech Rep., } \\
\text { Hungary }\end{array}$ \\
\hline III & low & $0,1811<\mathrm{di}<0,3481$ & $\begin{array}{l}\text { Latvia, Poland, Estonia, Lithuania, } \\
\text { Slovakia }\end{array}$ \\
\hline IV & very low & di $<0,1811$ & Bulgaria \\
\hline \multicolumn{5}{|c|}{ Year 2010 } \\
\hline ranking & level & criterion & \multicolumn{1}{|c|}{ Country } \\
\hline I & high & di $>0,4376$ & UE 15 \\
\hline II & middle & $0,2964<\mathrm{di}<0,4376$ & Czech Rep., Slovenia, Cyprus \\
\hline III & low & $0,1552<\mathrm{di}<0,2964$ & $\begin{array}{l}\text { Poland, Malta, Hungary, Slovakia, } \\
\text { Latvia, Lithuania, Estonia, Romania }\end{array}$ \\
\hline IV & very low & di $<0,1552$ & Bulgaria \\
\hline
\end{tabular}

Source: own calculations based on Eurostat (2012).

The results are consistent with the previous findings. A high level of implementation of the Lisbon Strategy is presented by only the EU-15 countries; a medium level by only three countries: Cyprus, the Czech Republic and Slovenia. Sadly, the majority of the New Members of the EU-27 (as many as eight countries in 2010) are characterized by a low level of the structural indicators analyzed. Again, both in 2000 and 2010, Bulgaria is definitely an outsider among the countries surveyed. 


\section{Conclusions}

This article has focused on analysing the differences in the implementation of the Lisbon Strategy goals among the 12 New Members and the EU-15 countries in 2000 and 2010. The reference point has been the results achieved by the EU-15 countries. The taxonomic analysis carried out allows some important conclusions to be drawn.

The European Union is an area with high differentiation among the 12 New Members and the EU-15 in terms of the levels of their structural indicators. This finding is confirmed by the synthetic value for each country analyzed. Also according to the Hellwig synthetic measure, in 2010 among the objects analyzed only the EU-15 countries have a high level of the indicators selected. Moreover, only three New Members belong to the group with an average level of these indicators, and as many as eight countries have a low level of implementation of the Lisbon Strategy. One country (Bulgaria) is evaluated as a country with a very low level of Lisbon Strategy implementation. These results confirm the hypothesis of a large gap between the EU-15 countries and the 12 New Members in implementing the key areas of the Lisbon Strategy.

The study has also revealed the instability of the similarity identified between countries in their degree of implementation of the Lisbon Strategy in 2000-2010. Although the number of large homogeneous clusters does not change during the period analyzed, the countries and the number of them included in each group change significantly. Therefore, these changes do not allow us to conclude that there exists a permanent pattern of structural ratios in each country among the 12 New Member countries.

Taking into account the Hellwig synthetic value, both in the years 2000 and 2010 Poland is classified in a group of countries with a low level of Lisbon Strategy implementation. The greatest structural weakness of the Polish economy is still low expenditures on research and development and a low employment rate, particularly among older people (55-64 years). The negative aspect of the Polish path towards the Lisbon Strategy goals is a drop of two places in the ranking of the EU countries analyzed in the years 2000-2010.

The conclusions of this analysis indicate that one of the reasons for the failure of the Lisbon Strategy could be big structural heterogeneity among EU counties. The structural differences become even bigger after two enlargements (2004, 2007), and some heterogeneity has already existed among the EU15 counties (Tilford \& Whyte, 2009).

We can make a hypothesis, and if the pace of structural change continues to be so slow among the New EU countries, the EU 28 as a whole will not be able to achieve the strategic objectives by 2020 . 
According to the author, it is necessary to determine by European Commission specific intermediate targets/recommendations to each of the New Member States, aimed at reducing the structural gap between them and the EU 15 countries. This will involve the development of an appropriate assessment methodology and the set of indicators, which can be used to measure the progress made towards the final goals of Europe 2020 Strategy.

Furthermore, the above analysis pointed out that the targets of Lisbon Strategy, as well as the Europe 2020 Strategy are significantly different in their nature and content. Prepared by EC set of indicators to assess the degree of implementation of the Strategy objectives, affects five very different areas of economic and social policy. Therefore, the author draws attention to the taxonomic method as an efficient way to compare the degree of Strategy implementation between EU countries, measured by 14 main (or 72 detailed) indicators.

\section{References}

Amstrong, K., Begg, I., \& Zeitlin, J. (2008), JCMS Symposium: EU governance after Lisbon. Journal of Common Market Studies, 46(2).

Arpaia, A., Hobza, A., \& Mourre, G. (2007). Quantitative assessment of structuralreforms: Modelling the Lisbon strategy. European Economy - Economic Papers, No. 282.

Balcerzak, A. ( 2011). Pozycja Polski w kontekście planu Europa 2020. Analiza z wykorzystaniem metod porządkowania liniowego. Studia Ekonomiczne / Uniwersytet Ekonomiczny w Katowicach, 81.

Balcerzak, A., Górecka, D., \& Rogalska, E. (2008). Taksonometryczna analiza realizacji strategii lizbońskiej w latach 2001-2005. Wiadomości Statystyczne, 6.

Brauers, W., Balezentis, T. \& Balezentis, A. (2011). Implementation of the Strategy Europe 2020 by the multi-objective evaluation method Multimoora. E\&M Ekonomie a Management, 14.

Brauers, W., Balezentis, A. \& Balezentis T. (2012). European Union Members States preparing for Europe 2020. An application of the Multimoora method. Technological and Economic Development of Economy, 18, http://dx.doi.org 110.3846/20294913.2012.734692.

Blanke, J. \& Kinnock, S. (2010). The Lisbon Review 2010: Towards a More Competitive Europe?. Retrieved from http://www.weforum.org/reports/lisbonrev iew-2010 (01.09.2013).

Barbier, J-C. (2010). Strategie de Lisbonne: Les promesses sociales non tenues. CES Working papers, No18.

Barbier, J-C. (2012). Tracing the fate of EU "social policy". Changes in political discourse from "Lisbon Strategy" to "Europe 2020". International Labour Review, 151. 
Barrel, R., \& Kirby, S. (2007). Notes on the Lisbon process - An analysis of the impacts of reaching the Lisbon targets for skills, $R \& D$ and the administrative burden in the European Union. Industrial Policy and Economic Reform Papers, 7.

Bertolini, P., \& Pagliacci, F. (2010). Lisbon strategy and EU countries' performance: social inclusion and sustainability. Working Paper of_Department of Economics of University of Modena and Reggio Emilia, No 0648.

Borsi, B. (2009). What the future of the Lisbon Strategy. Acta Oeconomica, 58.

Cantillon, B. (2010). Disambiguating Lisbon. Growth, Employment and Social Inclusion in the Investment state, CSB Working Paper, No 10/07.

Codogno, L., Odinet, G., \& Padrini, F. (2009). The Use of Targets In the Lisbon Strategy. Rivista Di Politica Economica, 99(1-3).

Destefanis, S. \& Mastromatteo, G. (2012). Assessing the reassessment: A panel analysis of the Lisbon Strategy. Economics Letters, 11(2).

Ederer, S., Janger, J., Kaniovski, S., Kletzan-Slamanig, D., Berger, J., Fortin, I., Hofer, H., Paterson I., Skriner, E., Schonpflug, K., Schuh U., \& Schwarzbauer W. (2010), The Lisbon Strategy 2005-2010 and Estimating Expected Effects from Reaching the EU 2020 Goals. WIFO, Wien.

European Commission (2004). Delivering Lisbon. Reforms for the enlarged Union.European Commission COM 29. Retrieved from http://www.ihep.org/a ssets/files/gcfp-files/Deliveriing_Lisbon_Reforms_Enlarged_Unio n_2004.pdf (16.07.2013).

European Commission (2005). Working Together For Growth and Jobs: A New Start for the Lisbon Strategy, European Commission COM, Retrieved from http://eur-lex.europa.eu/LexUriServ/site/en/com/2005/com2005_0024en 01.pdf (16.07.2013).

European Commission (2007). Proposal for a Community Lisbon Programme 2008-2010. COM 804 final. Retrieved from http://eurlex.europa.e u/LexUr iServ/LexUriServ.do?uri=COM:2007:0804:FIN:EN:PDF (16.07.2013).

European Commission (2010a). Europe 2020. A Strategy for smart, sustainable and inclusive growth. 2, $\operatorname{COM}(2010)$. Retrieved from http://eurlex.europa.eu/LexUriServ/LexUriServ.do?uri=COM:2010:2020:FIN:EN:PDF (16.07.2013).

European Commission (2010b). Lisbon Strategy: Evaluation Document. SEC 114 final. Retrieved from http://ec.europa.eu/europe2020/pdf/lisbon_strategy _evaluation_en.pdf (16.07.2013).

European Commission (2010c). An Agenda for new skills and jobs: A European contribution towards full employment, Strasbourg, COM(2010) 682 final, Retrieved from http://eurlex.europa.eu/LexUriServ/LexUriServ.do?uri=COM:2 010:0682:FIN:en:PDF (16.07.2013).

European Commission (2010d). Macro structural bottlenecks to growth in EU Member States, Brussels, $\operatorname{COM}(2010)$, Occasional papers, nr 65, Retrieved from http://ec.europa.eu/economy_finance/publications/occasional_paper/2010 /pdf/ocp65_en.pdf (16.07.2013). 
European Commission (2011). Tackling early school leaving: A key contribution to the Europe 2020, the European Economic and Social Committee and the Committee of Regions, Brussels, $\operatorname{COM}(2011) 18$ final. Retrieved from http://eur-lex.europa.eu/LexUriServ/LexUriServ.do?uri=COM:2011:0018:FI $\mathrm{N}: \mathrm{EN}: P D F(16.07 .2013)$.

European Parliament (2000). Lisbon European Council 23 and 24 March Presidency Conclusion. Retrieved from http://www.europarl.europa.eu/summi ts/lis1_en.htm (06.07.2013).

European Parliament (2010). The Lisbon Strategy 2000-2010. An analysis and evaluation of the methods used and results achieved. Report of Directorate General for Internal Policies: Employment and Social Affairs. Retrieved from http://www.europarl.europa.eu/document/activities/cont/201107/2011071 8ATT24270/20110718ATT24270EN.pdf (16.07.2013).

Eurostat (2012). Online Statistics database, Retrieved from http://epp.eurosta t.ec.europa.eu.

Everitt, B. S. (1993). Cluster Analysis. London: Edward Arnold Publishing. http://dx.doi.org/10.1002/9780470977811.

Everitt, B. S., Landau S., \& Leese M. (2001). Cluster Analysis. London: Edward Arnold Publishing.

Fischer, S., Gran, S., Hacker, B., Jakobi, A. P., Petzold, S., Pusch, T., \& Steinberg P. (2010). Europe 2020 - Proposals For the Post-Lisbon Strategy, Frankfurt: Friedrich Ebert Stiftung.

Gordon, A. D. (1999). Classification. Boca Raton: Chapman and Hall. http://dx.doi.org/10.1142/9789812832153 0003.

Grabiński, T. (1992). Metody taksonometrii. Kraków: Wydawnictwo Akademii Ekonomicznej w Krakowie.

Grabiński, T., Wydmus, S., \& Zeliaś, A. (1993). Metody prognozowania rozwoju społeczno-gospodarczego. Kraków: Wydawnictwo Akademii Ekonomicznej w Krakowie.

Gros, D. (2012). Perspectives on the Lisbon Strategy: How to increase European competitiveness in Europe after enlargement. Cambridge: Cambridge University Press.

Hellwig, Z. (1968). Zastosowanie metody taksonomicznej do typologicznego podziału krajów ze względu na poziom rozwoju oraz zasady i strukturę wykwalifikowanych kadr. Przegląd Statystyczny, 4.

Johansson, B., Karlsson, Ch., Backman, M., \& Juusola, P. (2007). The Lisbon Agenda from 2000 to 2010, CESIS - Electronic Working Paper Series, No. 106.

Johnson, R. A. \& Wichern, D.W. (2007). Applied Multivariate Statistical Analysis. Pearson Publishing.

Kaufman, L. \& Rousseeuw, P. J. (1990). Finding Groups in Data. New York: John Wiley \& Sons. http://dx.doi.org/10.1002/9780470316801.

Kedaitiene, A., \& Kedaitis, V. (2009). The Lisbon Strategy and Economic Growth. Ekonomika Ir Vadyba: Aktualijos Ir Perspektyvos, 2(15). 
Koczor, M., \& Tokarski, P. (2011). From Lisbon to Europe 2020, Lisbon Strategy Implementation in 2010: Assessments and Prospects, Warsaw: The Polish Institute for International Affairs.

Krings, T., Marlier, E., \& Natali, D. (2012). Europe 2020. Towards a more social EU?. Journal of European Social Policy, 22. http://dx.doi.org/10.1177/09589 28712440376.

Lenain, P., Bützow Mogensen, U., \& Royela-Mora V. (2005). Strategia Lizbońska na pótmetku: oczekiwania a rzeczywistość. Warszawa: CASE.

Nowak, E. (1990). Metody taksonomiczne w klasyfikacji obiektów społecznogospodarczych. Warszawa: PWN.

Moniz, A. (2011). From the Lisbon strategy to EU2020: illusion or progress for European economies? In: B.-J. Krings (Ed.). Brain Drain or Brain Gain? Changes of Work in Knowledge-based Societies. Berlin: Sigma Verlag.

Mundschenk, S. (2006). Competitiveness and Growth in Europe Lessons and Policy Implications for the Lisbon Strategy. Edward Elgar Publishing.

Panitsidou, E., Griva, E., \& Chostelidou D. (2012). European Union Policies on Lifelong Learning: In-between Competitiveness Enhancement and cial Stability Reinforcement. Procedia-Social and Behavioral Sciences, 46.

Papadimitriou, D., \& Copeland, P. (2012). The EU's Lisbon Strategy. Evaluating Success, Understanding Failure. Palgrave Macmillan.

Radło, M. J. (2006). Instruments to support structural reforms in Poland. In: M. Weresa Ed. Poland Competitiveness Report 2006, Warsaw: Warsaw School of Economics Publishing.

Rodrigues, M. J. (2009). Europe, Globalization And The Lisbon Agenda, Edward Elgard Publishing. http://dx.doi.org/10.4337/9781848446083.

Sojka, M. (2007). The Czech economy and the challenge of The Lisbon Strategy. Ekonoicky casopis, 55.

Soriano, F., \& Mulatero, F. (2010). Knowledge Policy in the EU: From Lisbon Strategy to Europe 2020. Journal of the Knowledge Economy, 4.

Strahl, D. (1978). Propozycja konstrukcji miary syntetycznej. Przeglad Statystycz$n y, 2$.

Tausch, A. (2009). Titanic 2010? The European Union and its failed Lisbon Strategy. Nova Science Publishers.

Teichman, E., \& Brocka-Palacz, B. (2009). Strategia Lizbońska z perspektywy wybranych krajów i regionów. Warszawa: Oficyna Wydawnicza SGH.

Tilford, S., \& Whyte, P. (2009). The Lisbon Scorecard IX. How to emerge from the wreckage, Centre for European Reform Publishing.

Treidler, O. (2011). Evaluating the Lisbon Strategy, Wirtschaftswissenschaftliche Beiträge des Lehrstuhls für Volkswirtschaftslehre, insbes. Wirtschaftsordnung und Sozialpolitik, 115.

Ward, J. H., Jr. (1963). Hierarchical Grouping to Optimize an Objective Function. Journal of the American Statistical Association, 48. http://dx.doi.org/10.230 7/2282967.

Vilpišauskas, R. (2012). Does Europe 2020 represent learning from the Lisbon strategy? In Europe and National Economic Transformation: the EU after the Lisbon Decade. Palgrave Macmillan. 
Zeliaś, A. (2002). Taksonomiczna analiza przestrzennego zróżnicowania poziomu życia w Polsce $w$ ujęciu dynamicznym. Kraków: Wydawnictwo Akademii Ekonomicznej w Krakowie.

Zgajewski, T., \& Hajjar, K. (2005), The Lisbon Strategy: Which failure? Whose failure? And why? Brussels Academia Press. 